\title{
HOMENAGEM DE ALUNOS COLÉGIO SANTA MARIA DE CURITIBA AO PRESIDENTE DUTRA
}

Esta foto mostra alunos do Colégio Santa Maria (Curitiba) em desfile escolar no qual prestam homenagem ao Presidente Eurico Gaspar Dutra que governou o Brasil no período de 1946 - 1951. Dutra assumiu o governo brasileiro após a queda de Getulio Vargas. Durante o período de Getulio Vargas, a educação escolar foi fortemente marcada pelo nacionalismo e personalismo. $\mathrm{O}$ nacionalismo valorizava $\mathrm{o}$ desenvolvimento brasileiro, os símbolos e a cultura nacionais, enquanto o personalismo enaltecia a figura do mandatário da nação como o patrocinador e provedor, principalmente no atendimento às necessidades do trabalhador. O governo de Eurico Gaspar Dutra marcou o período de redemocratização do Brasil, e a adesão ao capital internacional. No entanto, como bem mostra a fotografia, o culto à pessoa do Presidente permanecia como um forte traço do personalismo. Permaneciam também os desfiles escolares que, geralmente eram realizados no dia 5 de setembro, marcando os festejos da Semana da Pátria.

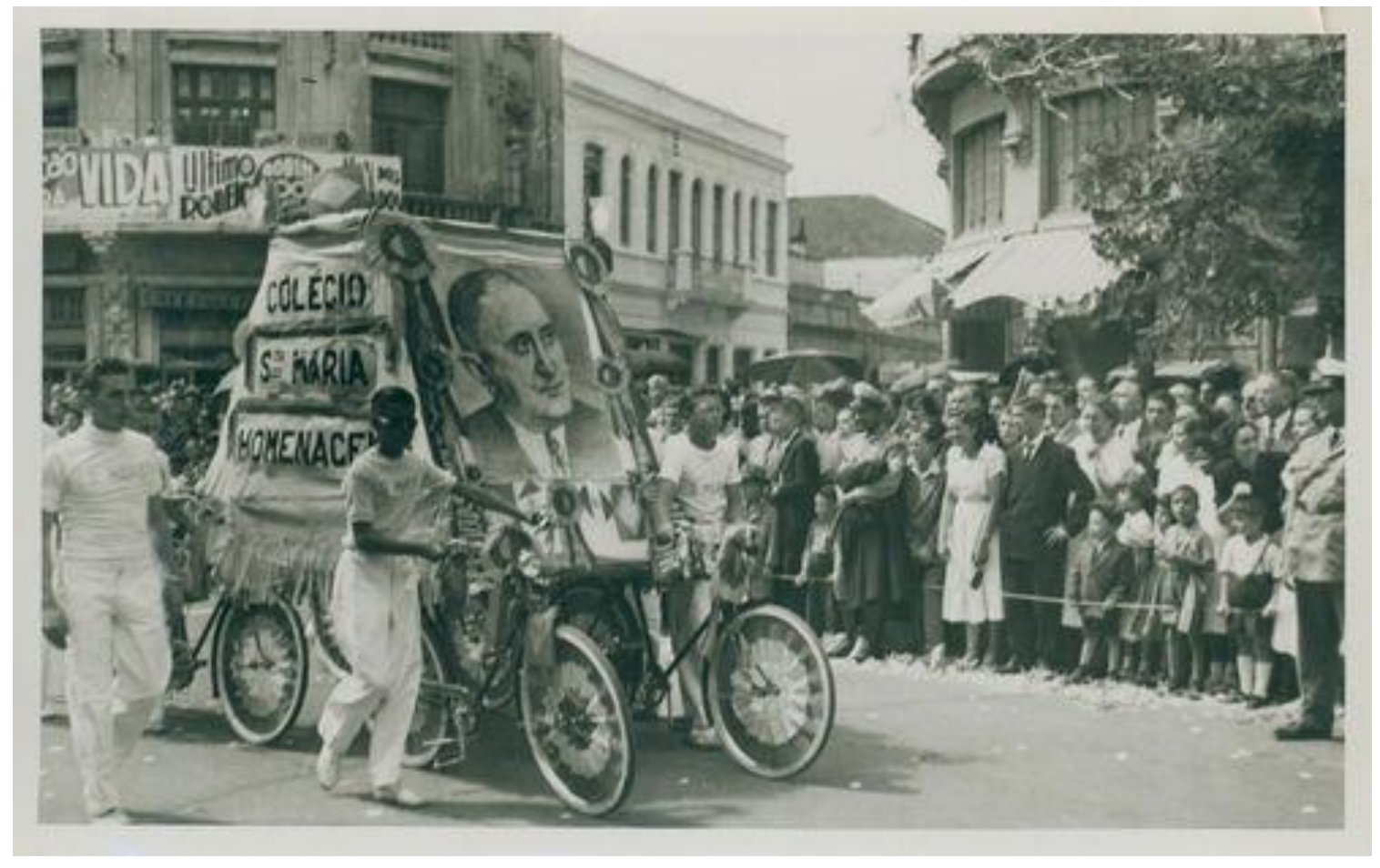

Fonte fotográfica disponibilizada pelo Arquivo Público do Paraná no site www.arquivopublico.pr.gov.br. Foto do Fundo Moysés Lupion.

Acesso em 28/12/2012 